\title{
Media training for future education professionals: A study of the Spanish Context
}

\author{
Carlos Rodríguez-Hoyos \\ rodriguezhc@unican.es \\ Departamento de Educación, Universidad de Cantabria \\ Aquilina Fueyo Gutiérrez \\ mafueyo@uniovi.es \\ Departamento de Ciencias de la Educación, Universidad de Oviedo
}

\begin{abstract}
This article presents the results of research aimed at finding out how training in media education is being developing in Spanish Universities. From a methodological perspective, this work is part of what can be considered a mixed research paradigm. In the first phase, the content of 179 study guides from 83 Spanish universities was analysed using a thematic coding system to analyse the data. In the second phase, 13 in-depth interviews were conducted with university teachers in charge of teaching subjects related to media education in order to understand how they were developing these experiences (methodologies used, systems of assessment, etc.). The results show that the presence of dimensions of media education in curricula is unequal and that teachers are using a wide range of teaching methods and evaluation tools. This study suggests that the education authorities and university teachers should rethink training for future teachers and include contents that facilitate understanding the functioning of the media as a way of accessing diverse cultural representations.
\end{abstract}

\section{Keywords}

Media; Media Education; Technology Education; Initial Teacher Training 


\section{Theoretical framework}

A number of international institutions have identified the need to improve the provision of education in the field of media and technology and have established policies with this aim. In 2008 UNESCO attempted to develop a global curriculum for teacher training in media education called "Cooperation Program on Media and Information Literacy and Intercultural Dialogue" which would be developed within the academic platform UNITWIN. Other institutions such as the Alliance of Civilizations and various universities from around the world also participated in this project (FrauMeigs \& Torrent, 2009). In 2011, the introduction of a curriculum for teachers was promoted aimed at enabling this group to develop a greater understanding of the role that the media and information technology plays in their lives and those of their students. In addition to establishing an area of contents and a series of teaching and learning strategies, this curriculum raised the need for creating a balance between the acquisition of knowledge and the process of a critical approach to the media, as suggested in several previous studies (Hoeschmann \& Poyntz, 2002; Livingstone, 2007). Meanwhile, the European Commission has repeatedly raised the need to influence the assessment criteria of levels of media literacy in Europe in its recommendations to all European Union states, highlighting the importance of promoting systematic research on its dimensions and on its level of development (Commission of the European Communities, 2009).

The review of specialised literature has shown that there is no international consensus when it comes to defining the best curriculum for media literacy (Potter, 2010). Although an analysis of diverse studies allows us to identify the basic concepts that media education curricula should include: the idea that the media are always constructions of reality (Tyner, 2014), the use of codes and conventions for the analysis and production of messages (Peppler \& Kafai, 2007), understanding the role of audiences (Ferguson, 2001), the analysis of the implicit ideology in messages (Giroux, 2011) and the study of media production processes (Buckingham, 2013).

In Spain research has been carried out which has identified the low level of media skills of its citizens (Ferrés et al., 2011; Ferrés, Aguaded, \& García-Matilla, 2012). Several international studies have demonstrated that the development of media education experiences in education systems is essential for reaching an adequate level of development of communication skills required by a society where there is a preponderance of information and communication technologies (Pelgrum, 2001; Tondeur, Ferrés, \& Valcke, 2007, Han, Eom, \& Shin, 2013).

Currently, primary and pre-elementary teaching qualifications in Spain are regulated by two legal texts which list the skills that students should have when they finish their degree (Ministerio de Educación y Ciencia, 2007a; Ministerio de Educación y Ciencia, 2007b). In these documents, the definition of these skills is open and imprecise. It states that teachers at both levels of education should have knowledge about audiovisual language and its educational implications and the educational and social impact of screens and audiovisual language. The definition of these skills in university study plans corresponds to each teacher.

The incorporation of media education in the training of education professionals in Spain is a recent development. In the 90's the first curriculums which allowed time for such content were developed in courses like Teaching, Pedagogy or Social Education. The subjects which were introduced then had different names but all of them belonged to the field which in different countries has been included within the discipline of Educational Technology (King, 2002) and introduced media education contents relevant to the training of future professionals from different levels of compulsory education for the first time. Some studies carried out previously in Spain show that the presence of subjects related to media education in curricula is scarce and that they are usually focused on issues such as managing technologies (Masanet \& Ferrés, 2012; Sancho \& Brain, 2013; Marta-Lazo, Grandío \& Gabelas, 2014). In this regard, some authors suggest the need to go 
beyond what is merely technological training, developing other skills that equip future teachers with the ability to accompany the social and cultural changes which are a consequence of the historical period they live in (Martínez, Leite \& Monteiro, 2016).

Some works aimed at analysing the development of skills for managing information technologies and communication from future teachers suggest that, despite the fact that this is clearly included in training programmes, students do not perceive an improvement in the management of technological resources (Cabezas, Casillas y Pinto, 2014; Maestre, Nail \& Rodríguez-Hidalgo, 2017). The results of research indicate that future teachers are aware of the need to manage resources properly in order to be able to respond to the new demands of today's society (Cabero, Llorente, Leal \& Lucero, 2009; Cózar y Roblizo, 2014), which is why diverse policies of initial and on-going training, which until now have proven to be inefficient, have been identified as one of the main problems in this area. (Gallego, Gámiz \& Gutiérrez, 2010; Prendes \& Gutiérrez, 2013).

The content analysis of curricula for teachers in training in Spain shows that they focus on the analysis of information products and that great importance is given to cognitive aspects versus emotional ones and the development of critical thinking (Ferrés \& Masanet, 2015). The treatment of these contents in curricula has been unequal, but it has always taken second place with respect to other contents focused mainly on the didactic use of communication media and new technologies (Díaz, Lucena, \& Martín, 2013). Nevertheless, it has followed a similar process as in the case of other countries where media education has been given more prominence, for example, such as in the United States (Kubey, 1998) or the United Kingdom (Wallis \& Buckingham, 2013).

In this regard, different studies developed internationally have highlighted some key factors for the development of media education such as the need to link theory to practice (Jeong, 2009), reduce the gap between what students take to the classroom and what teachers do methodologically with technologies (Kerawalla \& Crook, 2002; Ekanayake \& Wishart, 2014) or the importance of adequately combining analysis and media production (Kirk \& Pitches, 2013; Starkey, 2011).

\section{Research Aims and Questions}

This research was developed between 2011 and 2014 and its main objective was to understand how media education was being developed in various university qualifications within the field of education in Spain. Our study aims to answer the following questions:

1) How is media education conceived by some of the teachers involved in the development of subjects related to media education?

2) What are the dimensions of media education included in educational qualifications in Spain?

3) How are some of the curriculum elements of these subjects put into practice (pedagogy and assessment)?

Through our research we have been able to identify, on the one hand, the degree to which contents related to the different dimensions of media education were present in the curriculums of future education professionals by analyzing which dimensions received the most attention and which received less. On the other hand, this research has studied how some teachers in charge of developing subjects related to media education and the introduction of technologies in classrooms were developing their teaching. Lastly, we looked at how the initial training of education professionals is designed and based on this analysis we have made some recommendations on the future direction of guides, as well as suggesting more innovative alternatives from a methodological point of view. 


\section{Method, stages of research and data collection tools}

In this study, we used a mixed research paradigm (Jhonson \& Onwuegbuzie, 2004). This approach allowed us, on the one hand, to identify what dimensions of media education were being addressed in teaching guides and which were not, and to determine the percentages of each dimension present in the guides. We followed the example of other studies which have used quantitative data to statistically estimate the results of content analysis processes (Bearman et al., 2012). On the other hand, the process enabled us to understand the reality being studied, this being one of the main objectives of qualitative research (Denzin \& Lincoln, 2009). In this case, it was the analysis of the situation of media education in education courses in Spanish Universities. The data was collected both in public and private and universities with the aim of analysing the situation of the object of study in all higher education institutions in the Spanish territory in which there is teaching related to initial teacher training.

This research has been developed over two different phases. In the first phase, the study plans of the 83 Spanish universities where education studies are taught were analysed. During the first phase, an analysis was carried out of all the training courses in education studies published on the websites of all Spanish universities. Secondly, a database was created aimed at managing technologies and the media with the names of the subjects related to media education. Thirdly, a pilot study of the subjects to be analysed was carried out, ruling out those that did not have any links to media education. Following this, all the teaching guides were downloaded from the websites, in total 179 guides were analysed. Lastly, in order to carry out content analysis a coding system was defined through an inductive-deductive process, based on the six dimensions and indicators of media education proposed by Ferrés and Piscitelli (2012):

- Language: Knowledge and use of the codes through which languages are used to produce audio, written, visual and audiovisual messages.

- Production and diffusion processes: Understanding the processes of creation and diffusion by the mass media and social media.

- Interaction processes: Understanding the processes that are activated when media messages are received.

- Ideology and values: Reading and critical use and understanding mass and social media messages.

- Aesthetics: Extracting pleasure and the production of attractive media messages.

- Technology: The use of tools enabling media communication.

Not all the guides were in the same format which is why the contents of curriculum elements present in all the documents were analysed: skills, objectives and contents. The analysis of the contents of the teaching guides was carried out by pairs of experts. Each document was analysed independently by two researchers, thus developing a process of triangulation between experts (Johnson \& Turner, 2003). Firstly, each researcher independently analysed each guide determining whether there was evidence of the indicator in the objectives, contents and skills, adding this analysis to a database. Secondly, each expert analysed the coding carried out by their colleague, identifying if there was any disagreement with their work which was then discussed with the other expert. The work carried out by both researchers enabled the identification of the percentage of guides analysed in which each indicator was present or absent. The analysis of each guide was only added to the database when there was $100 \%$ agreement between the researchers on all the dimensions and indicators.

In the second phase of the research, we interviewed a sample of 13 teachers. We intentionally selected the teachers who appeared in the guides analysed and who taught subjects linked to 
media education. Therefore, the number of interviews carried out was within a range of between 10 and 15 (Kvale, 2011). The design of the semi-structured interview was based on the results obtained from the analysis of the teaching guides. The analysis of the dimensions and indicators present in the first phase of the study allowed us to identify the dimensions present or absent in the guides but they did not provide us with information on how they were developing in practice. To this end, a guide was created aimed at complementing these results and learning about aspects linked to the development of these curricula, such as their understanding of media education, the teaching methods used in their classes, the evaluation strategies or the materials used. By way of example, participants were questioned about the type of materials that they used in their classes, the individual study that their students had to do or the contents they gave most importance to in their subject. The interviews were conducted either in person or through a videoconferencing tool (such as Skype or Google Hangout). All of them were recorded and subsequently transcribed and returned to the interviewees so that they could change anything they deemed appropriate. To analyse the data a qualitative data analysis programme called MAXQDA was used and a coding system was set up using the following categories: the concept of media education, contents, methodological strategies and evaluation. The analysis was designed to identify units with their own meaning to which we assigned one of the codes included in the system of categories defined above. This process followed the phases identified by Huber (2003), that is, the reduction of the data gathered in interviews, the reconstruction of the structures and the comparison of the cases analysed.

\section{Findings}

In the following section we will outline the main results taken from the analysis of the data. The results of the analysis of the subject teaching guides and the interviews with the teachers are included in this section.

\section{a. Conceptions of media education}

The analysis of the interviews allowed us to identify that university teachers who taught subjects related to media studies in education courses dealt with two major views on this discipline which could be defined as instrumentalist and critical.

On the one hand, we can state that seven of the teachers interviewed maintained an "instrumental" conception of media education or one that was notably technological. This vision was based on the need, identified by the teachers themselves, to train future education professionals in the use of media in teaching, especially with regard to new technologies. In order to achieve this they maintained that it was necessary to design training processes in which last generation information and communication technologies were incorporated. Thus, these teachers considered that the instrumental use of technological devices (social networks, blogs etc.) amounted to the development of media education processes, as reflected in a quote by one of those interviewed:

"Media education facilitates both the consumption of the media as well as its use and administration to those we educate [...]. It has been useful for incorporating new media and ways of teaching using this new media, above all since the arrival of Smartphones or intelligent and touchscreen phones where you can change screens using a simple gesture or look." Interview 3.

On the other hand, this research has enabled us to state that six of the teachers did not have a conception of media education, which was radically different to what we could call "critical". These 
professionals promoted a view of the discipline focused on providing training that allowed students to understand what role the media and technologies have in society today. At the same time, they maintained that the final objective of these experiences should be aimed at reaching a set of skills that enable students to develop a critical vision for reading and using the media. From this perspective, they highlighted the need to work in university classrooms using media such as films or advertising in order to address, for example, the need to incorporate last generation media identified earlier.

"Activate people's critical awareness, that is give them the means to analyze, question and critically judge the messages they receive from various media, in order to encourage their participation and direct it towards safeguarding their rights and demanding higher quality media products." Interview 11

Nevertheless, it is important to point out that within this group, two teachers maintained an understanding closer to an instrumentalist vision of media education, giving excess relevance to the media as teaching aids because of their attractive and motivating nature.

\section{b. Dimensions}

The results obtained from analyzing the guides together with the interviews with the teachers are presented in this section. The results of these analyses show that teachers clearly prioritize some dimensions over others both in the documents used to design teaching-learning processes and in the development stage of these.

Overall, the dimension of media competence which appeared most in the guides of different education courses was that which referred to technology $(60.9 \%)$, followed by language $(20.8 \%)$. Similarly, two dimensions appeared in the guides related to the development of the process of diffusion and production (10.2\%) and the analysis of the ideology and values present in media texts $(12 \%)$. Finally, it can be noted that the two dimensions which appeared the least in education course guides were interaction processes (5.2\%) and aesthetics (3.2\%).

In the interviews carried out, the teachers of educational qualifications considered that the dimension that was most addressed in their classes was the ideological analysis of the media and the values that were represented in different products (series, cartoons, films, etc.). Within the framework of this dimension teachers analyzed diverse contents such as androcentrism and sexism present in the media, consumerism as well as the strategies of power or latent social control in the media.

On the contrary, with regard to the guides, this dimension was not the one which appeared the most in the contents. Only $12 \%$ of the guides addressed contents relating to this dimension. Out of these $20.7 \%$ of the guides contained contents related to the use of communication tools for the transmission of values and improving the environment as well as the development of a critical attitude and the ability to identify the ideology and values present in media texts. Contents related to the detection of stereotypes or messages that could infringe human values, the environment or the assessment, organization and selection of information from different settings were identified to a lesser extent ( $9.5 \%$ of the guides). Other indicators were also identified such as the development of strategies for managing emotions in front of screens according to the ideology and values transmitted $(7.3 \%)$ or the impulse towards an ethical attitude with regards to downloading products from the Internet $(4.3 \%)$. 


\begin{tabular}{|c|c|c|c|}
\hline Dimension & Indicator & Present \% & Absent\% \\
\hline \multirow{6}{*}{$\begin{array}{l}\text { Ideology } \\
\text { and values }\end{array}$} & $\begin{array}{l}\text { Assessment of the reliability of } \\
\text { sources of information from } \\
\text { different environments }\end{array}$ & $9.5 \%$ & $90.5 \%$ \\
\hline & $\begin{array}{l}\text { Identification explicit or latent } \\
\text { of ideology and values }\end{array}$ & $20.7 \%$ & $79.3 \%$ \\
\hline & $\begin{array}{l}\text { Ethical attitude when } \\
\text { downloading products from the } \\
\text { internet }\end{array}$ & $4.5 \%$ & $95.5 \%$ \\
\hline & $\begin{array}{l}\text { Identification stereotypes and } \\
\text { harmful messages }\end{array}$ & $9.5 \%$ & $90.5 \%$ \\
\hline & $\begin{array}{l}\text { Management of emotions in } \\
\text { interaction with screens }\end{array}$ & $7.3 \%$ & $92.7 \%$ \\
\hline & $\begin{array}{l}\text { Use of new communication tools } \\
\text { to transmit values and } \\
\text { contribute to the improvement } \\
\text { of the environment }\end{array}$ & $20.7 \%$ & $79.3 \%$ \\
\hline
\end{tabular}

Table 1. Percentages of the indicators of the ideology and values dimension present/absent in the guides.

Source: Own work

The second dimension most cited by teachers in the interviews was related to teaching different languages, generally involving the use of audiovisual technology. The teachers interviewed said that they worked with fixed and moving images and with sound. Within this dimension, the teachers stated that they developed contents such as the use of lighting, color, drawings, sound effects, etc.

"Language and ideology come to mind. [...] Language, we work mainly with the language of the image. And following this we apply it to the analysis of media products we reviewed. [...] Of course the basic signs of the image, how to read the image. And then ideology, through the analysis of values and counter values" Interview 1

This assessment coincides with the result of the analysis of the guides given that it is a dimension dealt with in $20.8 \%$ of them. Within this percentage $40.8 \%$ of the guides include contents aimed at making sure that students were able to interpret both the codes of representation as well as their expressive function. On the other hand, evidence of aspects relating to the possibility that students can produce and express themselves in a multimodal was found in only $16.2 \%$ of the guides analyzed. Meanwhile, it was observed that contents aimed at promoting the analysis of the relationship between texts, codes and media were identified in $13.4 \%$ of the documents, while $12.8 \%$ included aspects related to the analysis of narrative structures and conventions of different genres and media formats. 


\begin{tabular}{|c|c|c|c|}
\hline Dimension & Indicator & Present \% & Absent \% \\
\hline \multirow{4}{*}{ Languages } & $\begin{array}{l}\text { Interpretation and } \\
\text { evaluation of the codes of } \\
\text { representation and their } \\
\text { expressive function }\end{array}$ & $40.8 \%$ & $59.2 \%$ \\
\hline & $\begin{array}{l}\text { Analysis of the narrative } \\
\text { structures and the } \\
\text { convention of genres and } \\
\text { format }\end{array}$ & $12.8 \%$ & $87.2 \%$ \\
\hline & $\begin{array}{l}\text { Establishment of } \\
\text { relationship between texts }\end{array}$ & $13.4 \%$ & $86.6 \%$ \\
\hline & $\begin{array}{l}\text { Expression in a multimodal } \\
\text { way }\end{array}$ & $16.2 \%$ & $83.8 \%$ \\
\hline
\end{tabular}

Table 2. Percentages of the indicators of the dimension of languages present/absent in the guides.

Source: Own work

The teachers interviewed recognized that the technological dimension continues to be fundamental for the preparation of education professionals. It was noted that this dimension was the third aspect most addressed by those interviewed. Within this perspective, the teachers involved showed an interest in developing contents aimed at providing the necessary skills for managing different technological devices such as social networks, blogs and image editing tools, etc. It can be seen that in $79.9 \%$ of these cases reference was made to contents that were aimed at promoting understanding the social function of technologies by the student group. Contents directly linked to managing multimedia and multimodal tools were included in $62 \%$ of the texts analyzed. Meanwhile, in $40.8 \%$ of the guides analyzed contents aimed at promoting the ability of students to function in multimodal, hypermedia or transmedia environments was identified less frequently.

\begin{tabular}{|c|c|c|c|}
\hline Dimension & Indicator & Present \% & Absent $\%$ \\
\hline \multirow{3}{*}{ Technology } & $\begin{array}{l}\text { Social function of } \\
\text { technologies }\end{array}$ & $79.9 \%$ & $20.1 \%$ \\
\hline & $\begin{array}{ll}\text { Skills to work in } \\
\text { multimodal, } & \text { hypermedia } \\
\text { or } & \text { transmedia } \\
\text { environments } & \end{array}$ & $40.8 \%$ & $59.2 \%$ \\
\hline & $\begin{array}{l}\text { Managing multimedia and } \\
\text { multimodal tools }\end{array}$ & $62 \%$ & $38 \%$ \\
\hline
\end{tabular}

Table 3. Percentages of the indicators of the dimension technology present/absent in the guides.

Source: Own work

The analysis of the interviews allowed us to observe that there are some contents of media education that are being addressed very little within the framework of education courses. One of the dimensions developed less frequently, according to the teachers themselves, was related to the design of production and diffusion processes. Although, as can be seen in the following section 
analyzing methodological strategies, some teachers did demonstrate activities focused on the creation of small devices or media texts.

From the analysis of the guides it is apparent that the production and diffusion dimension is only present in $10.2 \%$ of the documents. The indicator that appeared most frequently in the guides was that which referred to collaborative work in relation to the creation of multimedia and multimodal products (18.4\%). Contents related to the processes of production, programming and diffusion of media texts appeared to a lesser extent (11.2\%). Meanwhile, in $9.5 \%$ of the guides analyzed evidence of work relating to the concept of authorship and the use of resources such as the Creative Commons, as well as managing regulatory and self-regulatory codes was identified. The indicators which appeared the least were those related to contents directed at disseminating information through different communication environments $(8.4 \%)$ and the development of responsible attitudes towards offline/online identity (4.5\%).

\begin{tabular}{|c|c|c|c|}
\hline Dimension & Indicator & Present \% & Absent \% \\
\hline \multirow{6}{*}{$\begin{array}{c}\text { Processes of } \\
\text { production } \\
\text { and } \\
\text { diffusion }\end{array}$} & $\begin{array}{l}\text { Knowledge of the systems of production, } \\
\text { programming and diffusion }\end{array}$ & $11.2 \%$ & $88.8 \%$ \\
\hline & $\begin{array}{l}\text { Knowledge of the regulatory and self- } \\
\text { regulatory codes }\end{array}$ & $9.5 \%$ & $90.5 \%$ \\
\hline & $\begin{array}{l}\text { Collaborative work in the development of } \\
\text { multimedia and multimodal products }\end{array}$ & $18.4 \%$ & $81.6 \%$ \\
\hline & $\begin{array}{l}\text { Sharing and disseminating information } \\
\text { through communicative environments }\end{array}$ & $8.4 \%$ & $91.6 \%$ \\
\hline & $\begin{array}{l}\text { Responsible attitude regarding their own } \\
\text { online/offline identity and that of others }\end{array}$ & $4.5 \%$ & $95.5 \%$ \\
\hline & $\begin{array}{l}\text { Managing the concept of individual and } \\
\text { collective authorship }\end{array}$ & $9.5 \%$ & $90.5 \%$ \\
\hline
\end{tabular}

Table 4. Percentages of the indicators of the processes of production and diffusion dimension present/absent in the guides.

Source: Own work

Both in the interviews carried out and in the analysis of the guides we can see that the two dimensions least addressed by the teachers were aesthetics and interaction processes. Contents aimed at providing the skills to interact with plural and intercultural groups could only be identified in $7.8 \%$ of the guides. In the subject guides aspects related to the selection and evaluation of the media diet also appeared and were identified in $7.3 \%$ of these documents. Other indicators such as understanding and managing emotions with regard to taste and cognitive effects (1.7\%) or the analysis of some basic concepts of media education such as audiences (3.9\%) appeared to a lesser extent. 


\begin{tabular}{|l|l|c|c|}
\hline Dimension & \multicolumn{1}{|c|}{ Indicator } & Present \% & Absent \% \\
\hline & $\begin{array}{l}\text { Selection and evaluation of the } \\
\text { media diet }\end{array}$ & $7.3 \%$ & $92.7 \%$ \\
\cline { 2 - 4 } $\begin{array}{l}\text { Interaction } \\
\text { processes }\end{array}$ & $\begin{array}{l}\text { Understanding and managing } \\
\text { emotions }\end{array}$ & $1.7 \%$ & $98.3 \%$ \\
\cline { 2 - 4 } & $\begin{array}{l}\text { Basic knowledge of the concept of } \\
\text { audience to interact with people and } \\
\text { groups in increasingly pluralistic } \\
\text { and multicultural environments }\end{array}$ & $7.8 \%$ & $96.1 \%$ \\
\hline
\end{tabular}

Table 5. Percentages of the indicators of the processes of interaction processes dimension present/absent in the guides.

Source: Own work

Without question, the aesthetic dimension was the one which was least present in the guides of the various education qualifications analyzed. Within this category contents related to the analysis of artistic products and the media were only identified in $7.3 \%$ of the guides. Contents aimed at developing the artistic side of students appeared less frequently (3.9\% of the guides). Meanwhile, evidence of the development of contents related to the identification of aesthetic categories such as the production of individual and collective media messages which were creative, sensitive and original were identified in $2.8 \%$ of the programs. In addition, contents which raised awareness with regard to the formal aspects of media texts ( $1.7 \%$ of the guides) or those aimed at developing the sensitivity required for analyzing the aesthetic quality of productions $(0.6 \%)$ also appeared.

\begin{tabular}{|c|c|c|c|}
\hline Dimension & Indicator & Present \% & Absent \% \\
\hline \multirow{6}{*}{ Aesthetic } & Identify formal aspects & $1.7 \%$ & $98.3 \%$ \\
\hline & $\begin{array}{l}\text { Detect low aesthetic quality } \\
\text { productions }\end{array}$ & $0.6 \%$ & $99.4 \%$ \\
\hline & $\begin{array}{l}\text { Relate media products with other } \\
\text { art forms }\end{array}$ & $7.3 \%$ & $92.7 \%$ \\
\hline & Identify basic aesthetic categories & $2.8 \%$ & $97.2 \%$ \\
\hline & $\begin{array}{l}\text { Produce messages with minimum } \\
\text { levels of creativity, originality and } \\
\text { sensitivity }\end{array}$ & $2.8 \%$ & $97.2 \%$ \\
\hline & $\begin{array}{l}\text { Transform artistic productions } \\
\text { enhancing creativity }\end{array}$ & $3.9 \%$ & $96.1 \%$ \\
\hline
\end{tabular}

Table 6. Percentages of the indicators of aesthetic dimension present/absent in the guides. Source: Own work 


\section{Pedagogy and assessment}

It should be noted that in Spanish universities teachers have the autonomy to choose the teaching methods that they are going to use in their classrooms and the strategies used to assess learning. All those interviewed acknowledged using different types of grouping methods when designing activities. All of teachers revealed that they tried to combine the development of individual activities with other collaborative ones, the latter being the ones most highly valued by students. Something which suggests, on the other hand, that this group is trying to move away from a sociocultural conception of learning in higher education classrooms.

"At first individual and groups activities are conducted based around a tool with the aim of mastering this technological tool and understanding its use, its potential for its educational use." Interview 4

Seven teachers demonstrated a contrary reaction to what is considered "traditional" pedagogy such as teacher based learning in such a way that either this was not used or was used sporadically during specific times during the subjects. In addition, to the type of grouping used in classrooms, it is important to point out that these teachers indicated that they were using different types of tools, some of which are recognised as belonging to the discipline of media education. In this regard, six of the teachers interviewed stated that a critical conception of media education also requires modifying assessment methods, which is why they sought to distance themselves from traditional forms of analysing students' work such as the use of exams or different types of tests.

We identified five teachers who measured students' performance using mixed systems in which the analysis of projects or activities was combined with other types of tests or written exams. Teachers argued that they were trying to establish a balance between formative and summative evaluation of the contents through the use of these types of strategies.

"Mostly I assess my students through work and oral presentations [...] Out of the two types, some work is carried out individually and other work in groups which means that I assess students individually and collectively." Interview 6

The analysis of the data showed that there are other teachers who were trying to carry out assessment strategies that could be considered as alternative. Two teachers stressed the importance of developing group evaluation systems, for which they used co-evaluation/peer assessment strategies, which attempted to be consistent with the approach of these types of projects. To facilitate this task, they resorted to the use of tools such as rubrics, which tried to facilitate the processes of analysis developed by the different groups of students. At the same time, one of the teachers interviewed said that they used self-evaluation as a strategy for developing the ability of metacognition in relation to learning developed by students throughout the subject.

Thus, six teachers explained that they developed textual analysis activities consisting of different types of media productions: cartoons, television series, films etc. The information supplied by teachers suggested that these types of activities took place accompanied by debates and exchanges in which students shared the results of their processes of analysis.

"We carry out a rigorous, textual analysis, we come across scenarios and we comment on them in relation to the objectives and contents of the subject. I think this is relatively surprising and new for students who are not used to this type of precise, textual and detailed analysis. " Interview 10

These six teachers understood that the textual analysis activities were a preliminary step before the development of production activities. The creation of short media texts in diverse formats (audio, visual etc.) should be carried out sequentially, taking into account that first it was 
necessary to teach reading the media so that the activities in which they were invited to create different types of productions could then be proposed.

"The emancipatory, critical and creative use of a medium or resource, that is where they are given the opportunity to express all this critical reception which has taken place over the semester. They have to hand in an audiovisual, multimedia document with a social background and hence use all their creativity." Interview 8

It is important to clarify that while teachers indicated that the production and diffusion dimension was one of the least developed dimensions in the classrooms of education studies when they were asked about them, the data analysis on methodological strategies enabled us to identify that all the teachers, except for two, reported the development of some type of production activity: the creation of audiovisual short films, radio programs, videoclips, presentations, the creation of tasks with QR codes etc.

Eleven teachers developed production strategies and they recognized the inherent complexity of implementing these types of activities and resorted to working in groups to promote the shared creation of media projects. In this regard, they tried to promote and encourage independent learning through two basic strategies: the creation of support networks between peers which allowed understanding the dynamics required for the creation and diffusion of media texts and the individual analysis of different sources (videos, texts, books, etc.). However, it is important to note that five teachers recognised that the "university grammar" which they perceived acts as a barrier limiting the development of diverse, rich and varied methodological strategies as illustrated in the following section.

"The system of one hour a week of theory, one hour of practice and then the following week you don't know when we might need to see each other the next day. There is a lot of inflexibility when it comes to timetables and space for this type of methodology." Interview 4

Furthermore, the analysis of the data showed that the value teachers gave to activities that, in their opinion, needed to be developed in the classrooms where qualifications linked to educational sciences are taught varied greatly. Three of those interviewed coincided in pointing out that the most relevant strategies were those which were linked to the textual analysis of media products (images, series, cartoons clips, films etc.) while the rest of the teachers identified aspects as diverse as the use of portfolios, the development of group activities, the development of didactic programs, the development of debates or reading and writing activities.

When teachers were interrogated over those aspects they considered to be more innovative within the context of their subjects, we could say that a uniform vision did not exist on what the development of innovative media education processes could mean, identifying three tendencies in their answers. For three teachers innovation was linked to the contents developed, either for being up to date or for their critical direction. Meanwhile, six teachers linked innovation to the use of technological devices, such as personal learning environments, the use of QR codes or audiovisual documents. We were able to identify four teachers who established a direct relationship between the idea of innovation and the development of methodological strategies such as group work or the implementation of strategies that encouraged and promoted student participation.

To sum up, the analysis of the data demonstrated that there was a certain contradiction between the type of practices developed by teachers and the evaluation systems used to measure student performance. Even those teachers who viewed media education from a critical perspective and who 
developed different group projects evaluated their students using individual strategies. Only two of the teachers interviewed said that they tried to break away from traditional, individual evaluation methods using peer evaluation strategies to assess learning.

\section{Conclusions}

Our research aims to provide information about the curriculum which influences teachers in the pre-active phase of teaching and how some of these teachers understand these proposals and how they interpret the effects caused by the curriculum in action (Gimeno, 1998). This study provides evidence that in curricula in education studies in Spain some contents related to the different dimensions of media education, developed by teachers, are being included, albeit to a limited extent. This finding is consistent with other previous studies that suggest a limited presence of the contents of media studies in teacher training (Masanet \& Ferrés, 2012; Marta-Lazo, Grandío \& Gabelas, 2014). It should be noted that in Spain certain parts of the curricula are regulated in law by the Ministry of Education which explains the presence of subjects such as educational technology (or others with similar names) in most Spanish faculties aimed at developing skills related to the management of different technological resources. In this regard, it is important to highlight that some recent studies carried out in Spain appear to show that training carried out in education faculties continues to be based on an instrumentalist view of technology (Díaz, Lucena, \& Martín, 2013; Colón, Moreno, León, \& Zagalaz, 2014).

The data analysis of the dimensions identified in the teaching guides (in which the most recurring dimension was technology) contrasts with the interviews in which teachers considered that the dimension most addressed in their classes is the analysis of the ideology of the media and its representations of reality as well as the one related to different languages. This could indicate a significant gap between what teachers include in curriculum design documents and what happens later in practice. The importance of the technological performance of future education professionals is undeniable as demonstrated in previous studies (Chai, Koh, \& Tsai, 2010; Chien, Chang, Yeh, \& Chang, 2012; O'Bannon, Lubke, \& Britt, 2013), but it needs to be combined with the development of the rest of the dimensions which are necessary in order to meet the challenges this group will face in classrooms when they begin work.

This study provides relevant information for education authorities and for teachers responsible for training future teachers internationally. On the one hand, education authorities responsible for managing higher education systems should develop evaluation processes, which enable analyzing to what extent all the dimensions of media education are being addressed in teaching qualifications. Neglecting any of these dimensions means that pre-service teachers will not have sufficient training in order to be able to teach citizens to participate in the media context in which they live. A number of studies have shown that the development of media education experiences in education systems is essential for reaching an appropriate level of development in the communication skills demanded by an information society (Pelgrum, 2001; Tondeur, Van Braak, \& Valcke, 2007).

On the other hand, education authorities need to adopt a more active role in defining and managing initial teacher training curricula in order to ensure that those contents necessary for meeting the demands of an interconnected world are addressed. The initial training received by teachers of different levels of compulsory education and in particular, the way in which skills and the contents of media education are regarded in this training as key elements to facilitating its development (Vrasidas \& McIsaac, 2001; Greenhow, Robelia \& Hughes, 2009). 
This study also has implications for those responsible for implementing pre-service teacher training. At present, the school institution has to assume responsibility for literacy using new codes or languages (such as sound or audiovisual formats for example) that are widespread and which are fundamental for accessing multiple and widely varied cultural representations produced by different cultural industries (Lankshear \& Knobel, 2008). Therefore, those responsible for training pre-service teachers need to design pedagogic practices that help their students understand that cultural transmission does not occur exclusively through the school curriculum, but rather there are other educational agents competing with the school to provide knowledge that is necessary for living in present times (Giroux, 2011).

The training required by a global inter-connected society goes beyond the technical management of technologies. The curricula of pre-service teachers should address issues related to the need to understand the social role of the media, becoming producers of messages in diverse languages using the technology at their disposal, carrying out processes of analysis of media texts and addressing issues related to the representation of variables such as ethnicity, gender or social class (Stack \& Kelly, 2006; Hobbs \& Jensen, 2009; Hoechsmann \& Poyntz, 2012). This research highlights the need to progress towards pedagogic practices in which future education professionals need to deal with the production and dissemination of messages, making use of the multiple channels and technologies that are available today. It also demonstrates the importance of developing concepts of media education that are not purely instrumental and move towards a global understanding of the role of the media and training in its critical use (Kellner \& Share, 2005).

Evidently, the selection of contents to work with in classrooms is a clear indicator of the direction that media education practice is taking and can be used to rethink which dimensions are not being developed and which need to be strengthened. This research demonstrates the need to move towards pedagogical practices in which future education professionals need to deal with the production and diffusion of messages, taking advantage of the multiple channels and technologies that are currently available to them. It also shows the importance of developing concepts of media education which are not purely instrumental and the need to progress towards a comprehensive understanding of the role of the media and move towards training in its critical use (Flores-Koulish, 2006).

The incorporation of such ideas in this type of initial training for teachers, educators and other education professionals will help, in the future, to train citizens who are capable of dealing with the informational complexity of the world we live in. Our study also highlights the need to strengthen methodologies used in future education professionals' media education with a view to involving them in projects, media production work, including the analysis of emotions, and making these methodologies consistent with forms of procedural and formative assessment where selfassessment and group assessment for work done collectively is taken into account.

The main limitation of this study is that it has focused on the analysis of the curricula of Spanish faculties of education. The results obtained suggest that research similar to other countries needs to be developed which enables the identification of how the media education of pre-service teachers is regarded with the aim of establishing and comparing the results obtained in other contexts.

\section{Funding}

This study was funded by: Ministerio de Ciencia e Innovación (Spain). Grant number: EDU201564015-C3-2-R. U. Pompeu Fabra 


\section{References}

Bearman, M, Smith, C., Carbone, A., Slade, S., Baik, Ch., Hughes-Warrnington, M., \& Neumann, D. (2012). Systematic methodology in higher education. Higher Education. Research \& Development, 31(5), 625-640. doi: 10.1080/07294360.2012.702735

Buckingham, D. (2013). Media education: Literacy, learning and contemporary culture. Malden, USA: John Wiley \& Sons.

Cabezas, M., Casillas, S., \& Pinto, A. M. (2014). Percepción de los alumnos de educación Primaria de la Universidad de Salamanca sobre su competencia digital. EDUTEC. Revista Electrónica de Tecnología Educativa, 48, 1-14.

Cabero, J., Llorente, M. C. Leal, F. \& Lucero, F. (2009). La alfabetización digital de los alumnos universitarios mexicanos: una investigación en la Universidad Autónoma de Tamaulipas. Enseñanza \& Teaching, 27(1), 41-59.

Chai, C. S., Koh, J. H., \& Tsai, C. C. (2010). Facilitating preservice teachers' development of technological, pedagogical, and content knowledge (TPACK). Educational Technology \& Society, 13(4), 63-73. Retrieved from http://www.jstor.org/stable/jeductechsoci.13.4.63

Chien, Y. T., Chang, C. Y., Yeh, T. K., \& Chang, K. E. (2012). Engaging pre-service science teachers to act as active designers of technology integration: A MAGDAIRE framework. Teaching and Teacher Education, 28(4), 578-588. doi: 10.1016/j.tate.2011.12.005

Colón, A. O., Moreno, L. A., León, M. P., \& Zagalaz, J. C. (2014). Formación en TIC de futuros maestros desde el análisis de la práctica en la Universidad de Jaén. Revista de medios y educación Pixel-Bit, 44, 127-142. doi: http://dx.doi.org/10.12795/pixelbit.2014.i44.09

Commission of the European Communities (2009). Commission recommendation 20.8.2009 on media literacy in the digital environment for a more competitive audiovisual and content industry and an inclusive knowledge society. Retrieved from http://eur-lex.europa.eu/legalcontent/EN/ALL/;ELX_SESSIONID=Ynp5JYdS9LGJ97FIsPZD4PdVXcR1YQ1NnxghpHGDGh9GMJzQG0Td!54549086? uri $=$ CELEX: $32009 \mathrm{H} 0625$

Cózar, R. \& Roblizo, M. J. (2014). La competencia digital en la formación de los futuros maestros: percepciones de los alumnos de los Grados de Maestro de la Facultad de Educación de Albacete. RELATEC. Revista Latinoamericana de Tecnología Educativa, 13(2), 119-133) Doi https://doi.org/10.17398/1695288X.13.2.119

Denzin, K. N., \& Lincoln, Y. S. (2009). The SAGE handbook of qualitative research (3 $3^{\text {rd }}$ ed.). Thousand Oaks, USA: Sage Publications.

Díaz, I. A., Lucena, F. J. H., \& Martín, F. D. (2013). Las actitudes de los docentes hacia la formación en tecnologías de la información y comunicación (TIC) aplicadas a la educación. Contextos educativos. Revista de Educación, 5, 253-270. doi: 10.18172/con.516

Ekanayake, T., \& Wishart, J. M. (2014). Developing teachers' pedagogical practice in teaching science lessons with mobile phones. Technology, Pedagogy and Education, 23(2), 131-150. doi: 10.1080/1475939X.2013.810366

Ferguson, B. (2001). Media education and the development of critical solidarity. Media Education Journal, 30, 37-44.

Ferrés, J. \& Masanet, M. J. (2015). Nuevos retos para la educación mediática. In J. Ferrés \& M. J. Masanet, (Ed.), La educación mediática en la universidad española (137-153). Barcelona, Spain, Gedisa.

Ferrés, J., \& Piscitelli, A. (2012). La competencia mediática: Propuesta articulada de dimensiones e indicadores. Revista Comunicar, 19(38), 75-82. doi: 10.3916/C38-2012-02-08 
Ferrés, J., García Matilla, A., Aguaded, Fernádez, J., Figueras, M., Blanes, M., Pousa, L., ...Zarandona, E. (2011). Competencia mediática: Investigación sobre el grado de competencia de la ciudadanía en España. Madrid, Spain: Instituto de Tecnologías Educativas.

Ferrés, J., Aguaded, I., \& García-Matilla, A. (2012). La competencia mediática de la ciudadanía española: dificultades y retos. Icono 14, 10(3), 23-42. doi: 10.7195/ri14.v10i3.201

Flores-Koulish, S. A. (2006). Media Literacy: An entrée for pre-service teachers into critical pedagogy. Teaching Education, 17(3), 239-249. doi: 10.1080/10476210600849706

Frau-Meigs, D., \& Torrent, J. (Ed.). (2009). Mapping media education policies in the world. Visions, programs and challenges. New York, NY, The United Nations-Alliance of Civilizations in co-operation with Grupo Comunicar.

Gallego, M.J., Gámiz, V. \& Gutiérrez, E. (2010). El futuro docente ante las competencias en el uso de las tecnologías de la información y comunicación para enseñar. EDUTEC. Revista electrónica de tecnología educativa, 34, 118, 1-18 Doi http://dx.doi.org/10.21556/edutec.2010.34.418

Greenhow, C., Robelia, B., \& Hughes, J. E. (2009). Learning, teaching, and scholarship in a digital age Web 2.0 and classroom research: What path should we take now? Educational Researcher, 38(4), 246-259. doi: $10.3102 / 0013189 \times 09336671$

Han, I., Eom, M., \& Shin, W. S. (2013). Multimedia case-based learning to enhance pre-service teachers' knowledge integration for teaching with technologies. Teaching and Teacher Education, 34, 122-129. doi: $10.1016 /$ j.tate.2013.03.006

Hobbs, R., \& Jensen, A. P. (2009). The past, present and future of media literacy education. Journal of Media Literacy Education, 1(1), 1-17.

Hoeschmann, M., \& Poyntz, S. (2002). Media literacies. A critical introduction. West Sussex, England: Blackwell Publishing.

Huber, G. L. (2003). Introducción al análisis cualitativo de datos. In A. Medina \& S. Castillo (Eds.), Metodología para la realización de proyectos de investigación y tesis doctorales (pp. 91-129). Madrid, Spain: Universitas.

Gimeno, J. (1998). El curriculum. Una reflexión sobre la práctica. Madrid, Spain: Editorial Morata.

Giroux, H. A. (2011). The crisis of public values in the age of the new media. Critical Studies in Media Communication, 28(1), 8-29. doi: 10.1080/15295036.2011.544618

Jeong, H. S. (2009). Media Education in South Korea: History, dynamics and challenges. In Ch. Chi-Kim (Ed.), Media education in Asia (pp. 63-77). New York, NY: Springer Science \& Business Media.

Johnson, R. B., \& Turner, L. A. (2003). Data collection strategies in mixed methods research. In A. Tashakkori \& Ch. Teddlie (Ed.), Handbook of mixed methods in social and behavioral research (pp. 297-319). Thousand Oaks, CA: Sage.

Johnson, R. B., \& Onwuegbuzie, A. (2004). Mixed methods research: A research paradigm whose time has come. Educational Researcher, 33(7), 14-26. doi: 10.3102/0013189x033007014

Kellner, D., \& Share, J. (2005). Toward critical media literacy: Core concepts, debates, organizations, and policy. Discourse: Studies in the cultural politics of education, 26(3), 369-386. doi: 10.1080/01596300500200169

Kerawalla, L., \& Crook, Ch. (2002). Children's computer use at home and at school: Context and continuity. British Educational Research Journal, 28(6), 751-771. doi: 10.1080/0141192022000019044

King, K. P. (2002). Educational technology professional development as transformative learning opportunities. Computers \& Education, 39(3), 283-297.

Kirk, C., \& Pitches, J. (2013). Digital reflection: Using digital technologies to enhance and embed creative processes. Technology, Pedagogy and Education, 22(2), 213-230. doi: 10.1080/1475939X.2013.768390 
Kubey, R. (1998). Obstacles to the development of media education in the United States. Journal of Communication, 48(1), 58-69. doi: 10.1111/j.1460-2466.1998.tb02737.x

Kvale, S. (2011). Las entrevistas en investigación cualitativa. Madrid, Spain: Morata.

Livingstone, S. (2007). On the material and the symbolic: Silverstone's double articulation of research traditions in new media studies. New Media \& Society, 9(1), 16-24. doi: 10.1177/1461444807075200

Lankshear, C., \& Knobel, M. (2008). Digital literacies: concepts, policies and practices. New York, USA: Peter Lang.

Maestre, M., Nail, O., \& Rodriguez-Hidalgo, A. J. (2017). Desarrollo de competencias TIC y para la educación inclusiva en la formación inicial práctica del Profesorado. Bordon. Revista de Pedagogía, 69(3), 57-72. Doi https://doi.org/10.13042/Bordon.2017.51110

Masanet, M. J., \& Ferrés, J. (2013). La enseñanza universitaria española en materia de educación mediática. Communication Papers, 2(2), 83-90.

Marta-Lazo, C., Grandío, M., \& Gabelas, J. A. (2014). La educación mediática en las titulaciones de Educación y Comunicación de las universidades españolas. Análisis de los recursos recomendados en las guías docentes. Vivat Academia, 17(126), 63-78. doi: http://dx.doi.org/10.15178/va.2014.126.63-78

Martínez, R., Leite, C., \& Monteiro, A. (2016). TIC y formación inicial de maestros: oportunidades y problemas desde la perspectiva de estudiantes. Cuadernos de Investigación Educativa, 7(1), 69-92. Doi https://doi.org/10.18861/cied.2016.7.1.2577

Ministerio de Educación y Ciencia (2007a). ORDEN ECI/3857/2007, de 27 de diciembre, por la que se establecen los requisitos para la verificación de los títulos universitarios oficiales que habiliten para el ejercicio de la profesión de Maestro en Educación Primaria. Retrieved from https://www.boe.es/boe/dias/2007/12/29/pdfs/A53747-53750.pdf

Ministerio de Educación y Ciencia (2007b). ORDEN ECI/3854/2007, de 27 de diciembre, por la que se establecen los requisitos para la verificación de los títulos universitarios oficiales que habiliten para el ejercicio de la profesión de Maestro en Educación Infantil. Retrieved from https://www.boe.es/boe/dias/2007/12/29/pdfs/A53735-53738.pdf

O'Bannon, B., Lubke, J. \& Britt, V. (2013). 'You still need that face-to-face communication': Drawing implications from preservice teachers' perceptions of wikis as a collaborative tool. Technology, Pedagogy and Education, 22(2), 135-152. doi: 10.1080/1475939X.2012.755470

Pelgrum, W. J. (2001). Obstacles to the integration of ICT in education: Results from a worldwide educational assessment. Computers \& Education, 37(2), 163-178. doi: 10.1016/S0360-1315(01)00045-8

Peppler, K. A., \& Kafai, Y. (2007). From SuperGoo to Scratch: Exploring creative digital media production in informal learning. Learning, Media and Technology, 32(2), 149-166. doi: 10.1080/17439880701343337

Potter, W. J. (2010). The state of media literacy. Journal of Broadcasting \& Electronic Media, 54(4), 675-696. doi: $10.1080 / 08838151.2011 .521462$

Prendes, M. P. \& Gutiérrez, I. (2013). Competencias tecnológicas del profesorado en las Universidades españolas. Revista de Educación, 361, 196-222 DOI: 10-4438/1988-592X-RE-2011-361-140

Price, L., \& Kirkwood, A. (2014). Informed design of educational technology for teaching and learning? Towards an evidence-informed model of good practice. Technology, Pedagogy and Education, 23(3), 325-347. doi: $10.1080 / 1475939 \times .2014 .942749$

Sancho, J. M. \& Brain, B. (2013). Cuando la sociedad digital solo es un eco: el caso de la formación inicial de los maestros de primaria. Digital Education Review, 24, 69-82.

Stack, M., \& Kelly, D. M. (2006). Popular media, education and resistance. Canadian Journal of Education, 29(1), 5-26. Retrieved from http://www.csse-scee.ca/CJE/Articles/FullText/CJE29-1/CJE29-1-stackkelly.pdf

Starkey, L. (2011). Evaluating learning in the 21st century: A digital age learning matrix. Technology, Pedagogy and Education, 20(1), 19-39. doi: 10.1080/1475939X.2011.554021 
Tondeur, J., Van Braak, J., \& Valcke, M. (2007). Curricula and the use of ICT in education: Two worlds apart? British Journal of Educational Technology, 38(6), 962-976. doi: 10.1111/j.1467-8535.2006.00680.x

Tyner, K. (2014). Literacy in a digital world: Teaching and learning in the age of information. New York, USA: Routledge.

Vrasidas, C., \& McIsaac, M. S. (2001). Integrating technology in teaching and teacher education: Implications for policy and curriculum reform. Educational Media International, 38(2-3), 127-132. doi: 10.1080/09523980110041944

Wallis, R., \& Buckingham, D. (2013). Arming the citizen-consumer: The invention of "media literacy" within UK communications policy. European Journal of Communication, 28(5), 527-540. doi: $10.1177 / 0267323113483605$

Zhao, Y. (2010). Preparing globally competent teachers: A new imperative for teacher education. Journal of Teacher Education, 61(5), 422-431. doi: 10.1177/0022487110375802 